\title{
コンクリートの圧縮強度試験結果に 影響を及ぼす各種試験条件
}

\author{
野 口 貴 文*
}

\begin{abstract}
概 要 同じバッチから得られ，同じ養生を施されたコンクリートであっても，その圧縮強度は各種試験条件の影響を 受けるため, 異なる試験結果が得られることがある。圧縮強度試験結果に影響を及ぼす試験体の条件としては, 形状, 寸 法, 高さ直径比, 端面処理状態, 構造体からのコアの採取方向などがあり, 試験時の条件としては, 試験体の乾湿状態・ 温度・設置状態，載荷速度などがある。また，試験機に関しては，加圧板の形状・寸法，球座の形状・寸法，軸方向およ び水平方向の剛性, 支柱の数などが圧縮強度試験結果に影響を及ぼす。特に, 高強度コンクリートでは, 今まで潜在的で あった各種試験条件についても特に注意を払う必要がある。

キーワード：圧縮強度, 試験条件, 試験体の形状, 端面処理, 載荷速度, 試験機, 高強度コンクリート
\end{abstract}

1.はじめに

「この压縮強度の值は，本当ですか？」などという不 可思議な（?）質問を受けた経験をお持ちの方はいませ んか？ 今まで何ら疑念を抱いたこともなかった圧縮強 度試験結果が信じてもらえないなんていう信じられない ような話が実はあるのです……。

現在, JCI 内に組織された二つの委員会においてコン クリートの各種試験法に関する検討がなされている。一 つは，JIS の見直し作業を行っている「コンクリート試 験方法 JIS 改正原案作成委員会」(委員長 : 町田篤彦埼 玉大学教授) であり，また，「ISO/TC 71 対応国内委員 会 WG-1」(委員長 : 辻 幸和群馬大学教授) では, ISO 試験法の策定および見直しに対する日本国内の意見の取 りまとめ作業が行われている。両委員会とも試験法の国 際整合化を目的として組織されたものであり, 建設製品 の国際的な流通および建設技術者の国際交流が世界的に 活発になってきたことがその背景となっている。

また，国際化と歩調を合わせる形で設計・施工基準の 性能規定化が推進されており, 近い将来, コンクリート の試験結果にも物理的な意味が要求されるようになるで あろう。その場合, 従来, 品質管理用としてもコンク リートの性能評価用としても用いられてきた一つの試験 法が, 物理的に明確な意味が要求される性能試験法と物
理的意味よりも品質管理を主目的とした品質管理試験法 の 2 種類に区分されるかもしれない。圧縮強度に限って いえば，表-1のように区分できるであろう。

一方, コンクリートの高性能化, すなわち, 高強度 化, 高流動化, 高耐久性化などが押し推められた結果,

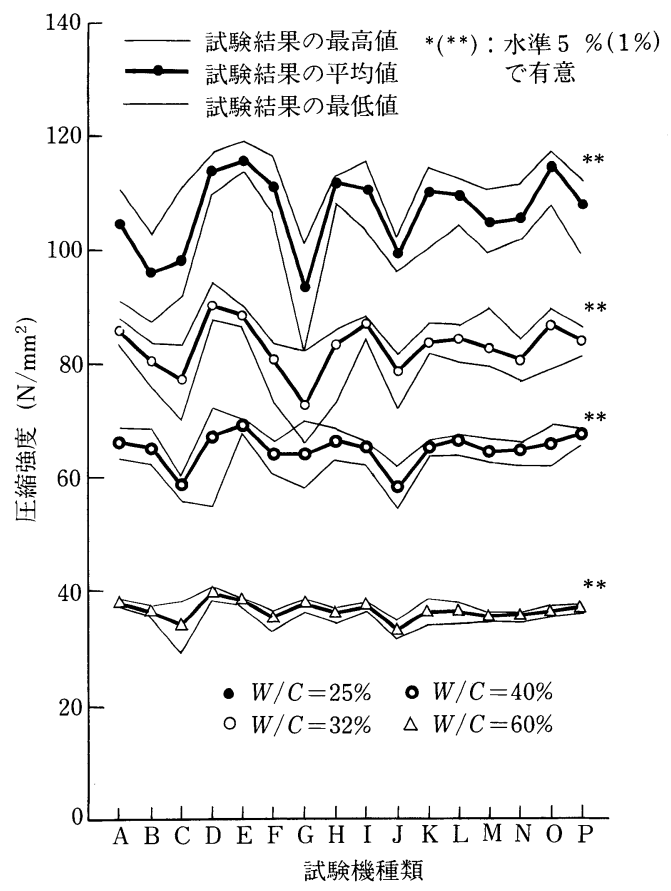

図-1＼cjkstart圧縮強度試験結果に及ぼす試験機種類の影響 ${ }^{1)}$

表-1 圧縮強度試験法の区分

\begin{tabular}{c|c|c}
\hline & 性 能 試 験 法 & \multicolumn{1}{c}{ 品質管理 試 験 法 } \\
\hline 目的 & $\begin{array}{l}\text { ・(設計に用いる設計基準強度) } \\
\text { ・解析に用いる一軸・多軸応力状態下の圧縮強度 }\end{array}$ & $\begin{array}{l}\text { ・レディーミクストコンクリート工場の品質管理 } \\
\text { ・レディーミクストコンクリートの受入検査 } \\
\text { ・構造体コンクリート強度の管理 }\end{array}$ \\
\hline 方法 & 目的に応じた応力状態が得られる試験法 & 従来の圧縮強度試験法 \\
\hline
\end{tabular}

* のぐち・たかふみ / 東京大学大学院助手 工学系研究科 建築学専攻（正会員） 
コンクリートが敏感になったため, これまで潜在化して いた試験条件の影響が顕在化し, 試験時にかなり入念な 注意を払わなければならなくなってきている。その一例 を図-1 に示す1)。これは，同一バッチから得られた同 一材料・同一調合のコンクリートを用いて同時に成形し た試験体の圧縮強度を, 同一材齢, 同一乾湿状態, 同一 載荷速度という条件下で, 表-2 に示す諸元・性能の異 なる 16 種類の圧縮試験機により測定した結果である が, 本来, 同一の圧縮強度試験結果が得られなければな らないはずのものが, 平均値において $10 \%$ 以上も異な る結果が得られている。特に, 高強度コンクリートにお いてその傾向は著しい。压縮強度はコンクリートの品質 を代表する最も基本的な指標であり，それが使用する試 験機によって異なることは, 設計上のみならず取引契約 上においても苦慮すべきことである。

表-2 圧縮試験機の諸元・性能

\begin{tabular}{|c|c|c|c|c|c|}
\hline 試験機 & $\begin{array}{c}\text { 最大科量 } \\
(\mathrm{kN})\end{array}$ & 制御方法 & $\begin{array}{l}\text { 軸 剛 性 } \\
(\mathrm{kN} / \mathrm{mm})\end{array}$ & $\begin{array}{c}\text { 加圧板寸法 } \\
(\mathrm{cm})\end{array}$ & $\begin{array}{l}\text { 球座の中心 } \\
\text { 位直 }(\mathrm{cm})\end{array}$ \\
\hline A & 1000 & 油圧荷重, サーボ & 218 & $\phi 16$ & +0.7 \\
\hline B & 2000 & 油圧荷重 & 440 & $\phi 21$ & +1.1 \\
\hline $\mathrm{C}$ & 1000 & 油圧荷重 & 218 & $22 \times 2222$ & +7.1 \\
\hline $\mathrm{D}$ & 2000 & ネジ式変位 & 635 & $30 \times 30$ & -0.2 \\
\hline $\mathrm{E}$ & 1000 & 油圧荷重 & 393 & $16 \times 16$ & \pm 0.0 \\
\hline $\mathrm{F}$ & 1000 & クサビ式変位 & 3100 & $\phi 22$ & -20.4 \\
\hline G & 5000 & 油圧荷重 & 707 & $\phi 15$ & +8.8 \\
\hline $\mathrm{H}$ & 1000 & 油圧荷重 & 453 & $\phi 16$ & \pm 0.0 \\
\hline I & 2000 & 油圧荷重 & 518 & $32 \times 32$ & \pm 0.0 \\
\hline $\mathrm{J}$ & 2000 & 油圧荷重 & 526 & $\phi 32$ & \pm 0.0 \\
\hline $\mathrm{K}$ & 2000 & 油圧荷重, サーボ & 906 & $\phi 16$ & +0.5 \\
\hline $\mathrm{L}$ & 1000 & 油圧荷重 & 259 & $\phi 16$ & +1.8 \\
\hline $\mathrm{M}$ & 4000 & 油圧変位, サーボ & 20000 & $\phi 16$ & -6.0 \\
\hline $\mathrm{N}$ & 1000 & 油圧荷重 & 303 & $\phi 16$ & +5.3 \\
\hline $\mathrm{O}$ & 1000 & 油圧荷重 & 356 & $\phi 23$ & \pm 0.0 \\
\hline $\mathrm{P}$ & 2000 & 油圧荷重 & 442 & $\phi 32$ & +8.3 \\
\hline
\end{tabular}

表-3 コンクリートの圧縮強度に影響を及ぼす要因

\begin{tabular}{|c|c|}
\hline 項目・時期 & 因 \\
\hline 材 & セメントの種類, 混和材の種類, 骨材の種類・寸法 \\
\hline 調 & $\begin{array}{l}\text { 水セメント比, 単位水量, 混和材量, 骨材量, 混和㓣 } \\
\text { 量, 空気量 }\end{array}$ \\
\hline 製 & 練混せ時間, 材料投入順序, コンクリート温度 \\
\hline 試験体の作製 & $\begin{array}{l}\text { 試験体の形状・法, } H / D \text {, 端面処理状態, 締固め程 } \\
\text { 度, 構造体からの試験体の採取位置・方向 }\end{array}$ \\
\hline 養 & 養生期間, 乾湿状態, 履歴温度 \\
\hline 試験体の状態 & 乾湿状態, 試験体の温度 \\
\hline 載 & 載荷速度, 試験体の設置状態, 応力状態 (一軸, 多軸) \\
\hline 試 験 機 & $\begin{array}{l}\text { 加圧板の形状 - 寸法, 球座の形状 - 寸法, 剛性, 支柱 } \\
\text { の数 }\end{array}$ \\
\hline
\end{tabular}

以上のように，何の疑いもなく日常的に扱われてきた コンクリートの圧縮強度を, 今一度注視する時が来てい るように思われる。压縮強度に影響を及ぼす要因を時系 列的に並べると，表-3 のようになるが，ここでは，コ ンクリートの試験体としての圧縮強度に的を絞り, それ に及ぼす各種要因の影響, 特に試験条件（内的要因, 外 的要因）の影響について解説する。

\section{2. 試験体に関わる要因（内的要因）}

\section{1 試験体の寸法}

均質なコンクリートでは，図-2 に示すように ${ }^{2)}$ ， あ る大きさまでは試験体寸法の増大に伴い圧縮強度試験結

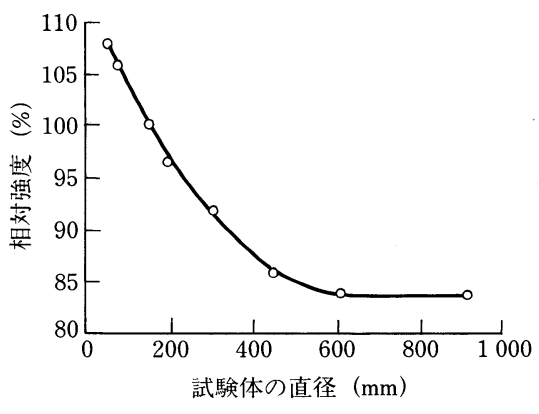

図-2＼cjkstart圧縮強度試験結果に及ぼす試験体寸法の影響 2$)$

Various Testing Conditions Affecting Measured Compressive Strength of Concrete

By Takafumi Noguchi

Concrete Journal, Vol. 35, No. 9, pp. 12 18, Sept. 1997

Synopsis Since compressive strength of concrete is affected by various testing conditions, identical concrete from the same batch and under the same cure sometimes produces different test results. Conditions of specimens affecting test results include size, shape, hight-diameter ratio, method of end preparation and coring direction from structure ; those at testing, humidity and temperature of specimen, setting, and loading rate. Such characteristics of testing machine as dimension of loading platen and spherically seated block, longitudinal and lateral stiffness, and number of supports also affect test results. In testing high strength concrete, special cares should be taken on various testing conditions whose effects have been latent in conventional concrete.

Keywords : compressive strength, testing condition, dimension of specimen, end preparation, loading rate, testing machine, high strength concrete 
果が低下するといった，寸法効果が存在することが知ら れている。その原因に関しては, 試験体中の欠陥量の多 少に依存する容積効果に立脚した確率過程理論による説 明 ${ }^{3)}$ 之, 破壊の発生・伝播過程におけるエネルギー平衡 問題に立脚した破壊力学による説明 ${ }^{4)}$ がなされている。 ここで注意しなければならないのは, 試験体の均質度, すなわち, 骨材寸法に対する試験体寸法の比およびマト リックスと骨材の力学的性質の違いが寸法効果に大きな 影響を及ばす点である ${ }^{5)}$ 。通常の強度レベルのコンク リートでは, 骨材の弾性係数はマトリックスの弾性係数 よりもかなり大きい。そのため, 試験体寸法が骨材寸法 と比較してあまり大きくない状態では, 試験体の均質度 が低いので, 試験体寸法を小さくしても圧縮強度が高く ならない場合がある。一方, 高強度コンクリートでは, マトリックスと骨材の間に大きな力学的性質の違いはな くなり，寸法効果が顕著に現れるようになる ${ }^{6)}$ 。

\section{2 試験体の形状}

コンクリートの圧縮強度試験に, 日本・アメリカ・フ ランスなどでは円柱体を用いているが，イギリス・ドィ ツなどでは立法体を用いている。それぞれ，長所・短所 を有しているため, 現在のところ世界的な統一はなされ ておらず，両者の関係が換算表の形で示されていること が多い7)。両者には, 次項に述べる高さ直径比の効果と 同様な関係があり, 立法体の方が円柱体よりも一般的に 高い圧縮強度試験結果を示すが，コンクリート強度が高 くなるほど両者の差は小さくなる。ただし，コンクリー 卜の打込み方向と載荷方向の関係が両者の間では異なる ため, 分離気味のコンクリートが用いられる場合には, 破壊の進展過程に違いが生じ, 立法供試体の方が低い強 度を示す場合もある8

\section{3 高さ直径比}

構造体コンクリートの压縮強度を評価するために構造 体から切り出したコアを用いて試験する場合, 試験体の 高さが直径の 2 倍以下になることもある。その場合, 加 压板と試験体端面との摩擦による端面拘束効果のため, 図-3に示すように ${ }^{9)}$, 高さ直径比が 2 の場合よりも高 い圧縮強度試験結果が得られるので, JIS A 1107 には 高さ直径比に応じた補正係数が示されている。しかし, この補正係数の值はコンクリートの均質度によって異な

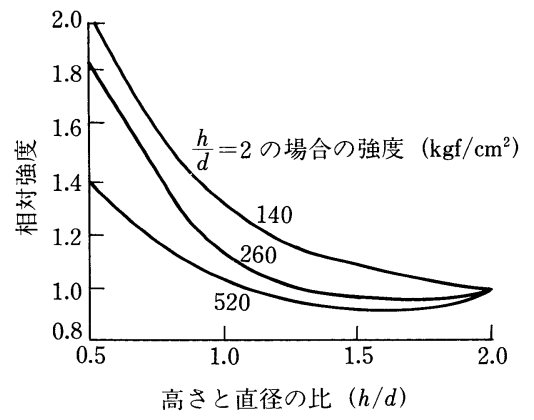

図-3＼cjkstart圧縮強度試験結果に及ぼす高さ直径比の影響9)
り，コンクリートの均質度が高いほど，すなわち高強度 であるほど，あるいはマトリックスと骨材の力学的性質 が近似しているほど, 高さ直径比の影響は小さくなる。 したがって，本来ならば，強度レベルならびに使用骨材 の種類（軽量骨材の場合, 高強度コンクリートに近い性 状を示す）に応じて，異なる補正係数を用いる必要があ る。普通骨材を用いた場合に限られるが，(1) 式のよう な強度の影響を盛り込んだ補正係数の算出式も示されて いる6)。

$$
\begin{gathered}
n=k\{\ln (2 D / H)\}^{2}+1 \\
k=4.84 / \sigma_{B}+0.165
\end{gathered}
$$

$n: \sigma_{B}$ に対する压縮強度比, $H:$ 高さ, $D$ : 直径

$\sigma_{B}: H / D=2$ の試験体の圧縮強度 $\left(\mathrm{N} / \mathrm{mm}^{2}\right)$

\section{4 端面処理状態}

試験体として円柱を用いる場合には，一般的に仕上げ 面（端面）が載荷面となるため, 端面を適切な方法で平 滑に仕上げなければならない。JIS A 1132 には端面処 理方法としてさまざまな方法が示されているが，コンク リートの高強度化に伴い, 現状の端面処理方法の適否に ついて疑問が投げかけられ（図-4，高強度コンクリー トには機械研磨を施すことが推奨されている ${ }^{10)}$ 。基本 的に, キャッピングを施すことによって, 載荷中, コン クリートとキャッピング材の力学的性質の違いに起因す る水平力が試験体端面に生じてはならず，また，コンク リートよりも先にキャッピング材が破壊してはならな い。こうした観点から, 端面処理方法それぞれについて 適用可能な強度範囲を設定しようとする動きも本格化 （ISO 化）してきており，そこでも機械研磨による方法 が強度制限のない標準的な方法として示されている。一 方, キャッピングを施す場合にも，その厚さは $3 \mathrm{~mm}$ が望ましく, $8 \mathrm{~mm}$ を越えてはならないと ASTM C 617 には規定されている。その根拠について以下のよう な説明がなされている8)。キャッピングが薄い場合に は, キャッピングとコンクリート端面との間に空隙が生 じやすく，また高荷重下でキャッピングが割裂しやすい

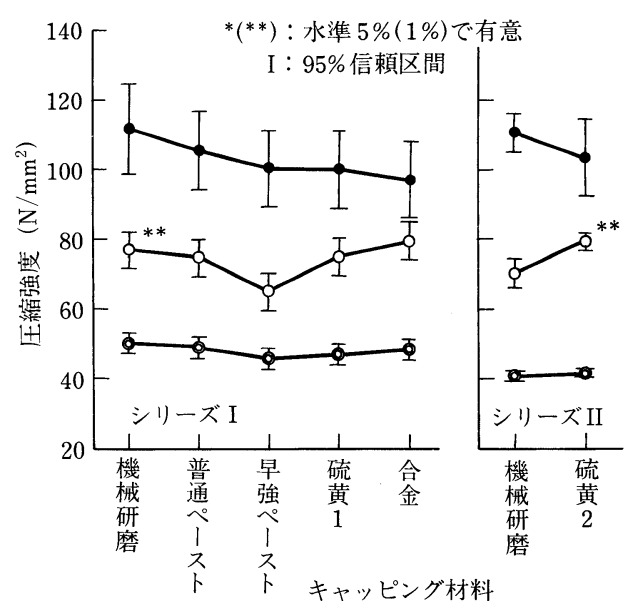

図-4＼cjkstart圧縮強度試験結果に及ぼすキャッピング材 料の影響 ${ }^{10}$ 


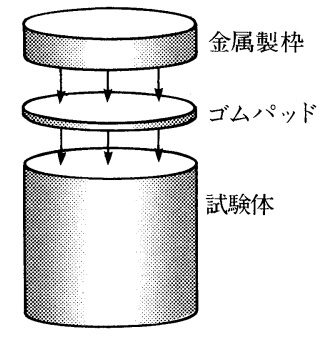

図-5 Unbonded Capping

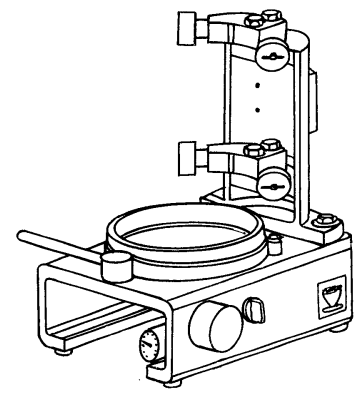

図-6 Sand-Box 用治具

ため，圧縮強度試験結果の低下が生じる。一方，キャッ ピングが厚い場合には，キャッピング材の弾性係数はコ ンクリートよりも一般的に小さいので，ポアソン効果に より載荷に伴いキャッピングが水平方向に変形し，コン クリート端部に引張応力が生じてしまうため, 圧縮強度 試験結果の低下が生じる。

また，キャッピングを施す前のコンクリート端面の形 状も圧縮強度試験結果に影響を及ぼし，端部が凸状で あったり，傾斜しているような場合には圧縮強度試駼結 果の低下を生じさせる ${ }^{11)}$ 。

最近, 端面処理作業にかかる時間・労力・経費を節減 することを目的として，新たな端面処理方法が世界的に 画策されている。一つは，図-5に示すような，剛な金 属製の枠に拘束されたゴムパッドを介して荷重を伝達す る機構を有した Unbonded Capping であり, 压縮強度 が $70 \mathrm{~N} / \mathrm{mm}^{2}$ までのコンクリートであれば適用可能で あることが示されている12) 14)。また，図-6に示すよ うなゴムパッドの代わりに細かい砂を用いる “Sand Box” という方法も提案されており ${ }^{15)}$ ，压縮強度が 100 $\mathrm{N} / \mathrm{mm}^{2}$ までのコンクリートに適用可能であることが示 されている。一方，我が国においても，アルミニウム粉 末および高性能減水剤を添加した膨張性流動化ペース卜 を用いてキャッピングを行う ZKT 法 ${ }^{16)}$ が提案されてい る。

\section{5 試験体の乾湿状態および温度}

養生条件が同じコンクリート試験体であっても, 試験 時の試験体の含水状態が異なれば，圧縮強度試験結果に 差が生じる。乾燥した試験体は，含水状態の試験体より も20２5\% 高い圧縮強度を示すと言われており，その 原因については，含水状態のコンクリートでは，セメン トペースト中の水分が圧縮されて硬化体を分離する圧力 を生じさせるためという説明 ${ }^{17)}$ と，乾燥したコンク リートでは, 表面近傍に生じた収縮が内部コンクリート を拘束するためという説明18)がなされている。

また，図一7に示すように，試験時の試験体の温度が 低いほど，コンクリートの強度は高くなる ${ }^{19), 20) 。 そ の ~}$ 原因は，コンクリート中の自由水や吸着水が凍結するこ とにより, 間隙が強度を有する水で充てんされ, 水がセ メント水和物の膠結物質として作用するためであると解

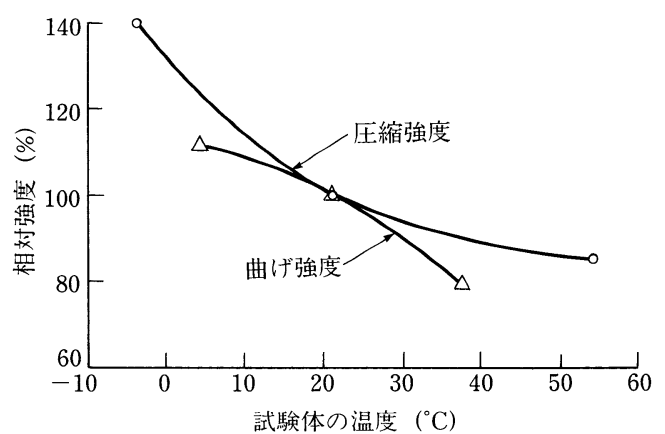

図-7 圧縮強度試験結果に及ぼす試験体温度の影響19)

釈されている。

3. 試験機に関わる要因（外的要因）

\section{1 試験体の設置状態}

試験体の中心軸と試験機の載荷軸が一致していない場 合には，圧縮強度試験結果の低下が生じる。1 $13 \mathrm{~mm}$ の 軸のずれで $10 \%$ 程度の強度低下が生じる場合があ $り^{21)}$ ，この傾向はコンクリートの強度が高いほど顕著 である ${ }^{22)}$ 。ただし，この偏心載荷による強度低下は， 後ほど「3.4 球座に塗布する潤滑剤」で述べるように, 球座の回転性能と密接な関係がある。

コンクリートの打込み方向と載荷方向の関係は，圧縮 強度試験結果に少なからず影響を及ぼす。特に分離抵抗 性の優れていないコンクリートを立方体で試験する場合 には，これ以外にも試験体の向きに注意する必要があ る。すなわち，コンクリートの打込み方向と載荷方向が 垂直な場合には，断面内で打込み上面から下面に向かっ て力学的に弱くなるため, 変形が弱点部（打込み上面） に偏り曲げ压縮状態になるとともに，図-8に示すよう に骨材下面の欠陥の向きが載荷方向之平行になるた め $^{23)}$, 骨材下面の欠陥からのクラックの進展が容易に 促され，10\% 程度の圧縮強度試験結果の低下を生じ

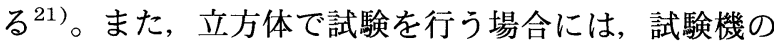
横方向への変形を抑えるため, 打込み面を試験機の支 柱側に向けて試験を行う必要がある。

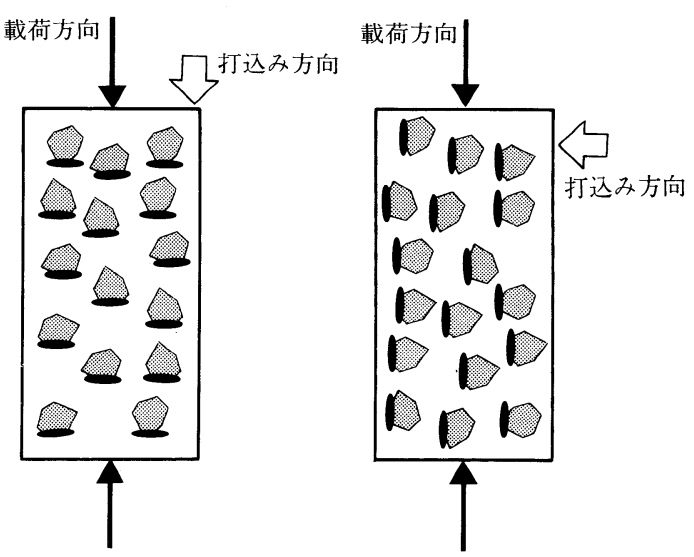

図-8 コンクリートの打込み方向と載荷方向の関係 


\section{2 載荷速度}

載荷速度が大きくなるほど圧縮強度試験結果が高くな ること，ならびに圧縮強度の 75 \% $95 \%$ 程度までの応力 状態（体積ひずみが減少から増大に転じる点）に達する までの載荷速度は圧縮強度試験結果に影響を及ぼさない ことは周知の事実である。しかしながら, 載荷速度の影 響とコンクリート強度との関係については統一した見解 は得られていない。すなわち, 強度レベルが高いほど載 荷速度の影響が顕著になるという見解 ${ }^{24)}$ と，その逆の 見解 25 がある。

\section{3 球座・加圧板の形状・法}

コンクリートの圧縮強度試験に用いられる試験機は, 加圧面に中心を有する球座を持っていなければならない こと (JIS B 7733) が JIS A 1108 に規定されている が，加圧板および球座の形状・寸法についての規定はな く，表-2に示すようにさまざまな加圧板・球座が用い られている。しかし，図-9に示すように，その形状の 違いによって, コンクリートの上部に生じる応力状態は 異なってくる19)。これが，同じコンクリートであって も異なる試験結果および異なる破壊形式が生じる原因の 一つとなっている ${ }^{22,26)}$ 。試験体に均等に応力を伝達す ることのできる球座・加圧板の形状を調べるために行わ れた有限要素解析の結果によれば, 荷重幅 $W(\mathrm{~cm})$ お よび加圧板厚さ $D(\mathrm{~cm})$ には, 図-10に示すように均等 な応力伝達を達成できる範囲が存在し，(2) 式のように

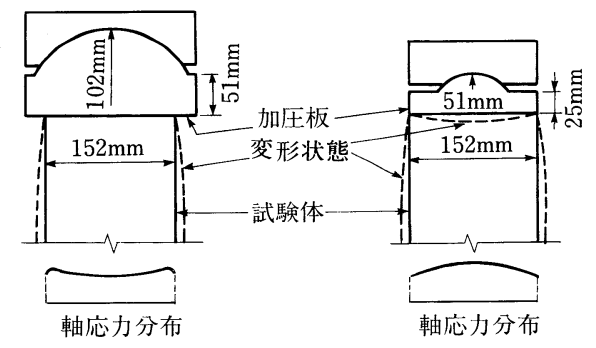
(a) 風な加圧板
(b) 柔な加圧板

図-9 試験体端部の応力状態に及ぼす加圧板の影響19)
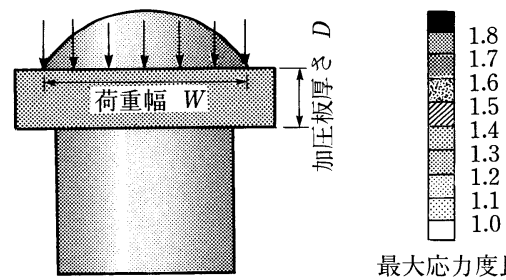

最大応力度比

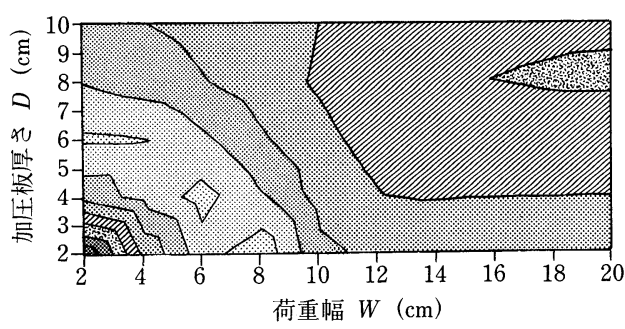

図-10 球座・加圧板の形状・法之供試体上部の 最大圧縮応力との関係 ${ }^{27)}$
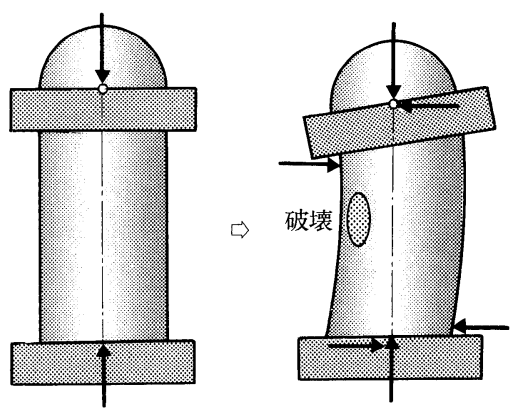

図-11 球座の中心が加圧面上にない 場合の載荷状態

数式で表現されている ${ }^{27) 。}$

$$
64 \leqq W^{2}+D^{2} \leqq 100 \text { かつ } 2 \leqq D
$$

また，図一11に示すように球座の中心が加圧面上にな い場合には，載荷に伴って試験体の一部に破壊が生じ， 軸方向の変形が不均等になると, 球座がその動きに追従 するため試験体に水平力が作用し, 対角線に沿って試験 体が破壊する可能性が高くなる22)。

\section{4 球座に塗布する潤滑剤}

試験体設置後加圧板が試験体の載荷面に容易に密着で きるように, 球座の表面には潤滑剤が塗られている。し かしながら, 潤滑剤の種類がコンクリートの圧縮強度試 験結果に大きな影響を及ぼし，しかも，図-12 に示すよ うに，その影響はコンクリート強度が高いほど顕著であ ること ${ }^{22)}$ はあまり知られていない。高応力下でも潤滑 作用を有する高性能な潤滑剂を用いた場合には，載荷中 においても球面座の回転が可能であるため, 試験体の一 部に破壊が生じて軸方向の応力・変形分布が断面内で不

\begin{tabular}{|c|c|c|}
\hline 潤滑剤の種類 & $\begin{array}{l}\text { 動粘度 }\left(40^{\circ} \mathrm{C}\right) \text {-鉱物油 } \\
\text { 混和ちょう度一グリース }\end{array}$ & 途 \\
\hline 鉱物 油 $\mathrm{A}$ & $135 \sim 165 \mathrm{cSt}$ & \multirow{4}{*}{ 工業用ギヤー油 } \\
\hline 鉱 物 油 B & $612 \sim 748 \mathrm{cSt}$ & \\
\hline 鉱 物 油 C & $1350 \sim 1650 \mathrm{cSt}$ & \\
\hline 鉱物 油 D & $4140 \sim 5060 \mathrm{cSt}$ & \\
\hline グリース $\mathrm{A}$ & $355 \sim 385$ & 一般用, カップグリース \\
\hline グリース B & $265 \sim 295$ & $\begin{array}{l}\text { 高荷重用, 二硫化モリブデ } \\
\text { 含有 }\end{array}$ \\
\hline
\end{tabular}

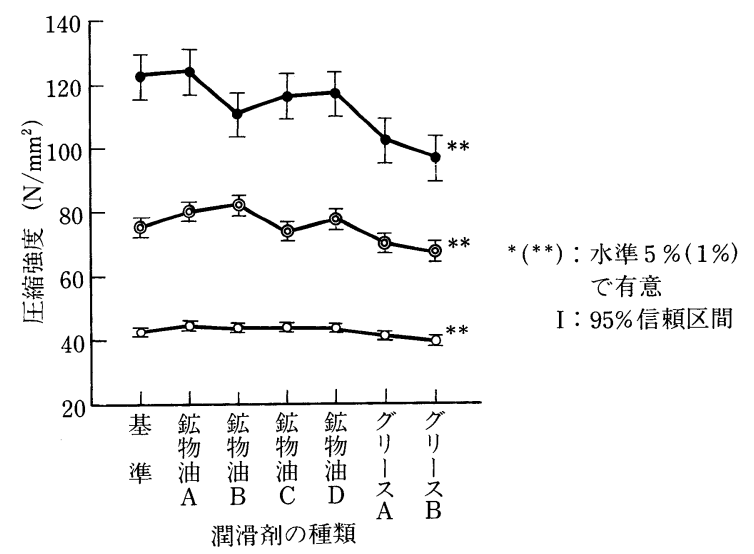

図-12 圧縮強度試験結果に及ぼす球面座潤滑剂の 種類の影響 22$)$ 


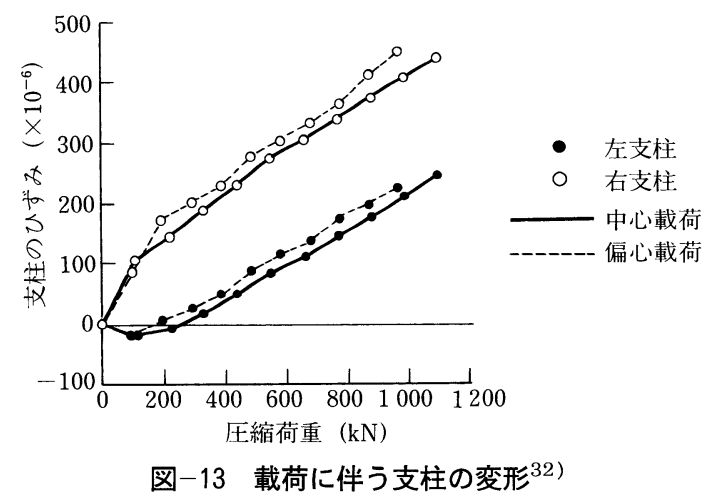

均等になった場合 (偏心載荷), 球座はその動きに容易 に追随する。その結果, 試験体に生じた局部破壊を一層 助長させることとなり, 圧縮強度試験結果を低下させ る。通常の強度レベルのコンクリートでは, 局部破壊が 発生してから試験体全体の崩壊に至るまでに, さらに破 壊領域の拡大が必要になるが, 高強度コンクリートで は, 局部破壊が全体崩壊に容易に繫がるため, 載荷中の 球面座の回転により压縮強度試験結果の低下を生じやす い。強度低下を生じさせないようにするためには, 載荷 後に球座の回転を抑制できるような比較的粘性の低い鉱 物油を潤滑剤として用いる必要がある。

\section{5 試験機の剛性}

試験機の㴊性（支柱の太さおよびクロスヘッドの曲げ 剛性が大きく関与) がコンクリートの圧縮強度試験結果 に及ぼす影響については，その影響の有無を含めて，賛 否の別れるところである。剛性の影響に否定的な見 解 28 もあるが, 肯定的な見解に関しては, 試験機に蓄 積されたエネルギーの試験体への流入を考虑した破壊力 学的な観点から, 剛性の低い試験機ほど圧縮強度試験結 果が低下し，その影響はコンクリートの強度が高いほど 顕著であるという説明 ${ }^{29), 30)}$ がなされている。また, 試 験機のクロスヘッドの追従性の観点からも, 剛性の低い 試験機ほど圧縮強度試験結果が低下するという説明 ${ }^{31)}$ がなされている。

コンクリートの压縮強度試験に用いられる試験機は支 柱を 2 本有しているものが多い。載荷中, この左右 2 本 の支柱に生じるひずみは本来等しくなければならない が, 図-13に示すように，2 倍近い差が生じている場合 がある。左右の支柱のひずみが均等でないと, 試験体に 曲げ荷重を与えるだけでなく, 支柱に蓄積されるエネル ギーも増大してしまうため, 圧縮強度試験結果の低下を 生じさせる可能性がある ${ }^{32)}$ 。

\section{4.おわりに}

以上, 压縮強度というコンクリートにとって最も基本 的な性質について，それに及ぼす各種試験条件の影響を 述べた。この問題は, 既に 1910 年代には研究対象とし て取り上げられていたこと年からもわかるように，非
常に数多くの研究者によって取り組まれてきた問題であ る。現在, 世界的な試験方法の統一が画策される中で, 先人たちの残した形跡は大いに役立つであろう。

\section{参 考 文 献}

1) 友澤史紀・野口貴文ほか: 高強度コンクリートの圧縮強度試験方 法の標準化に関する研究 (その 4, その 5), 日本建築学会大会学 術講演梗概集, A, pp. 499 502, 1990

2) R. F. Blanks and C. C. Macnamara : Mass Concrete Tests in Large Cylinders, Journal of American Concrete Institute, Vol. 31, pp. 280-303, 1935

3) H. Mihashi and M. Izumi : A Stochastic Theory for Concrete Fracture, Cement and Concrete Research, Vol. 7, pp. $411-422,1977$

4) 長谷川俊昭・岡田武二 : コンクリート材料の破壊と寸法効果, 七 メント技術年報, 40, pp. $241 \sim 244$, 昭和 61 年

5）谷川恭雄・山田和夫 : コンクリートの王縮強度の寸法効果につい て, 日本建築学会論文報告集, 第 262 号, pp. 13 21, 昭和 52 年

6）野口貴文・友澤史紀 : 高強度コンクリートの压縮力学特性に及ぼ す供試体寸法・形状の影響, 日本建築学会構造系論文集, No. 473, pp. 19〜28, 1995

7) 例えば, CEB-FIP Model Code 1990

8) W. T. Hester : Field Testing High-Strength Concrete, A Critical Review of the State-of-the-Art, Concrete International, pp. 27-38, 1980

9) J. K. Murdock and C. E. Kesler : Effect of Length to Diameter Ratio of Specimen on the Apparent Compressive Strength of Concrete, ASTM Bulletin, No. 221, pp. 68-73, 1957

10）野口貴文・友澤史紀 : 高強度コンクリートの厈縮強度試験結果に 及ぼす供試体の上面処理方法の影響, 日本建築学会構造系論文 集, No. 475, pp. 1 7, 1995

11) H. F. Gonnerman : Effect of End Condition of Cylinder in Compression Tests of Concrete, Proceedings of ASTM, Vol. 24, Part II, pp. 1036-1065, 1924

12) P. M. Carrasquillo and R. L. Carrasquillo : Effect of Using Unbonded Capping Systems on the Compressive Strength of Concrete Cylinders, ACI Materials Journal, Vol. 85 , No. 3, pp. 141-147, 1988

13) D. N. Richardson : Effects of Testing Variables on the Comparison of Neoprene Pad and Sulfur Mortar-Capped Concrete Test Cylinders, ACI Materials Journal, Vol. 87, No. 5, pp. 489-495, 1990

14）野口貴文・友澤史紀ほか: 高強度コンクリートの圧縮強度試験方 法の標準化 (その 10), 日本建築学会大会学術講演梗概集, A, pp. 957 958, 1993

15) C. Boulay and F. de Larrard : Capping High-Performance Concrete Cylinders with the 'Sand-Box', Proceedings of 3rd International Symposium on Utilization of High-Strength Concrete, pp. 1015-1037, 1993

16) 吉兼 亨: キャッピングの迅速化に向けて, セメント・コンク リート, No. 540, pp. 8〜17, 1992

17) P. K. Mehta and P. J. M. Monteiro : Concrete, Structures, Properties, and Materials (Second Edition), Prentice Hall, p. 61, 1993

18) S. Popovics : Effect of Curing Method and Final Moisture Condition on Compressive Strength of Concrete, Journal of American Concrete Institute, Vol. 83, pp. 650-657, 1986

19) A. M. Neville : Properties of Concrete (3rd Edition), Pitman, p. 558, 1981

20）三井健郎・米澤敏男・井上孝之 : 超高強度コンクリートの極低温 環境下での力学特性に関する研究, コンクリート工学年次論文報 告集, Vol. 19, No. 1, pp. 175〜180, 1997

21) P. Klieger and F. Lamond : Signicificance of Tests and Properties of Concrete and Concrete-Making Materials, ASTM, pp. 126-130, 1994

22）野口貴文・友澤史紀 : 高強度コンクリートの圧縮強度試験結果に 及ぼす球面座の挙動の影響, 日本建築学会構造系論文集, No. 478, pp. 9 18, 1995

23) S. Mindess and J. F. Yound : Concrete, Prentice-Hall, p. 439, 1981 
24) D. A. Abrams : Effect of Rate of Application of Load on the Compressive Strength of Concrete, Proceedings of ASTM, Vol. 17, Part II, pp. 364-377, 1917

25) F. Tomosawa, T. Noguchi, et. al. : Proceedings of 3rd International Symposium on Utilization of High-Strength Concrete, pp. 1255-1262, 1993

26) M. Lessard and P. C. Aitcin : Testing High Performance Concrete, High Performance Concrete from Material to Structure, Chapman \& Hall, pp. 196-213, 1992

27) T. Noguchi and F. Tomosawa : Effect of Characteristics of Testing Machine on Measured Compressive Strength of High Strength Concrete, Proceedings of 4 th International Symposium on Utilization of High-Strength and HighPerformance Concrete, pp. 301-308, 1996
28) O. T. Sigvaldason : The Influence of Testing Machine Characteristics upon the Cube and Cylinder Strength of Concrete, Magazine of Concrete Research, Vol. 18, No. 57, pp. 197-206, 1966

29）野口貴文・友澤史紀・小野山貫造 : コンクリートの圧縮強度に及 ぼす試験機剛性の影響, コンクリート工学年次論文報告集, Vol. 12, No. 1 , pp. $251 \sim 256,1990$

30) J. Glucklich and L. J. Cohen : Strain-Energy and Size Effects in a Brittle Material, Materials Research \& Standards, ASTM, Vol. 8, pp17-22, 1968

31) 岡田 清・六車 熙編: コンクリート工学ハンドブック, 朝倉書 店, p. 379,1981

32）野口貴文: 高強度コンクリートの基礎的力学特性に関する研究, 東京大学学位論文, 1994

\section{コンクリート便覧（第二版）}

社団法人 日本コンクリート工学協会編

\footnotetext{
B 5 判・980ページ/定価 31500 円

[主要目次]

第 1 編 コンクリート概説

定義および種類／特性と用途／構造方式および工法／コンク リート技術の発展

第 2 編 コンクリート材料

セメント /骨材 / 水 /混和材料 / 補強材料

第 3 編 コンクリートの配(調)合と製造

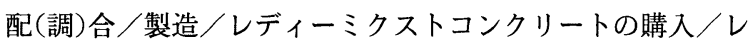
ディーミクストコンクリートの製造

第 4 編 コンクリートの性質

フレッシュコンクリートの性質／硬化コンクリートの性質／

コンクリートの耐久性

第 5 編 コンクリートの施工

施工計画 /型枠／鉄筋工／運搬／打込み・締固め/継目・表 面仕上げ・養生／品質管理・品質検査／寒中コンクリート／ 暑中コンクリート/マスコンクリート

第 6 編 特殊なコンクリートの材料・施工

高強度／高流動／軽量／緘維補強／超速硬／膨張・無収縮／ ポリマーセメント・ポリマーおよびポリマー含浸／充填材／ 水密／海洋／耐熱／耐食／気泡

第 7 編 各種コンクリート構造物の施工

水中コンクリート工法/吹付けコンクリート（モルタル）工 法/スライディングフォーム工法/プレキャストコンクリー ト工法/プレストレストコンクリート工法／舗装コンクリー ト/トンネルコンクリート/ダムコンクリート／原子力関連 施設コンクリート/長大橋コンクリート基礎構造物／大規模 地中タンク／超高層 $\mathrm{RC}$ 造建築物／特殊工法

第 8 編 コンクリート製品

コンクリート製品/セグメント／土留め・護岸製品/パイル ・ポール /管類/プレストレストコンクリート橋桁／道路用

製品／鉄道用製品／建築用製品／景観コンクリート製品

第 9 編 維持管理

基本 /構造物の劣化の予測 / 点検 /劣化度の評価之判定 /対 策／維持管理（補修・補強）の実例

第10編 試 験

コンクリートの材料の試験／フレッシュコンクリートの試

験／硬化コンクリートの試験／耐久性に関する試験／部材お よび構造物のモデル試験／実構造物の試験および検查／施工 機械の試験

第11編＼cjkstart鉄筋コンクリートの概要

成り立ち／力学（プレストレストコンクリートを含む）／設 計法の概要
}

\section{-申込先：技報堂出版（株）営業部}

テ107 東京都港区赤坂 1-11-41 第一興和ビル

電話 (03) 3585-0166/FAX. (03) 3505-5838

〈申込方法〉技報堂出版㑣営業部宛て，電話またはファクシミリにてお申込み下さい。 